\title{
SNOW DURATION EFFECTS ON DENSITY OF THE ALPINE ENDEMIC PLANT PACKERA FRANCISCANA
}

\author{
James F. Fowler ${ }^{1,2}$ and Steven Overby ${ }^{1}$
}

\begin{abstract}
AвstRact.-Packera franciscana (Greene) W.A. Weber and Á. Löve (Asteraceae) (San Francisco Peaks ragwort) is an alpine-zone endemic of the San Francisco Peaks in northern Arizona. Previous studies have shown that $P$. franciscana is patchily distributed in alpine-zone talus habitats. The purpose of this study was to describe the relationship between snow duration and $P$. franciscana abundance. We established trailside transects through $P$. franciscana habitat along the Weatherford Trail to estimate the abundance of $P$. franciscana ramets. Snow-free and snowbed sample segments were chosen based on a 17 May 2013 snow photograph taken from within the Inner Basin of the San Francisco Peaks caldera. The section of the Weatherford Trail under snow on 17 May 2013 had a 5-year arithmetic mean of 1.53 ramets $\cdot \mathrm{m}^{-2}$ (SE 0.37)—much less dense than the snow-free section which had a 5-year arithmetic mean of 7.17 ramets $\cdot \mathrm{m}^{-2}(\mathrm{SE} 1.09)$. The steep upper portion of talus slopes is known to move downslope faster than mid- and lower slope portions due to gravitational processes working on surface particle size, slope angle, and frost heave/needle ice during moist periods. Needle ice is known to uproot seedlings in other species. Active talus shift may inhibit $P$. franciscana colonization and growth on upper talus slopes via high seedling mortality in the snowbed zone during spring snowmelt.
\end{abstract}

Resumen.-Packera franciscana (Greene) W.A. Weber y Á. Love (Asteraceae) (los Picos de Hierba Cana de San Francisco) se encuentra en una zona alpina endémica de los Picos de San Francisco, en el norte de Arizona. Estudios previos han mostrado que $P$. franciscana se distribuye irregularmente en hábitats de talud alpinos. El propósito de este estudio fue describir la relación entre la duración de la nieve y la abundancia de $P$. franciscana. Establecimos transectos transversales a lo largo del hábitat de $P$. franciscana en Weatherford Trail para estimar la abundancia de rametos de P. franciscana. Elegimos los segmentos con y sin nieve en base a una fotografía de una nevada tomada el 17 de mayo del 2013 desde la cuenca interior de la caldera de los Picos de San Francisco. Esta sección perteneciente a Weatherford Trail bajo nieve del día 17 de mayo del 2013, presentaba una aritmética de cinco años de 1.53 rametos $\cdot \mathrm{m}^{-2}(\mathrm{SE} 0.37)$, mucho menos densa que la sección libre de nieve que tenía un promedio aritmético de cinco años de 7.17 rametos $\cdot \mathrm{m}^{-2}$ (SE 1.09). Se sabe que la parte superior del talus se mueve hacia abajo más rápidamente que las porciones de pendiente media y baja debido a los procesos gravitacionales que actúan en el tamaño de las partículas de la superficie, el ángulo de inclinación y el levantamiento por helada/agujas de hielo durante periodos húmedos. Se sabe que el fenómeno de aguja de hielo (pipkrake) arranca de raíz las plántulas de otras especies. La pendiente activa puede inhibir la colonización de $P$. franciscana y el crecimiento de pendientes superiores a través de la alta mortalidad de plántulas en la zona de lecho de nieve durante el deshielo de primavera.

Plant ecologists have long noted that rocky talus slopes are somewhat bare but have patches of vegetation in favorable microsites (Barbour et al. 1987). Few studies have examined the distribution of plants on alpine talus, especially with regard to seasonal snow duration. Packera franciscana (Greene) W.A. Weber and Á. Löve (Asteraceae), the San Francisco Peaks ragwort, is a single-mountain, alpinezone endemic (Fowler et al. 2014) found only in upper treeline and alpine habitats of the San Francisco Peaks in northern Arizona (Greenman 1917, Barkley 1988, Trock 2006; Fig. 1). It is a cryptophyte (geophyte) with creeping, branched rhizomes characteristic of talus species in Packera (Barkley 1962, 1968).
Packera franciscana, as Senecio franciscanus Greene (Greene 1889), was listed as a threatened species under the Endangered Species Act (ESA) by the U.S. Fish and Wildlife Service (USFWS 1983) due to its narrow geographic distribution and volcanic talus habitat specificity, as well as concerns over recreational impacts. During previous research fieldwork on this species (Fowler et al. 2015), we noted that it is spatially distributed in patches along trailside transects in alpinezone talus habitats of the San Francisco Peaks. One segment of the Inner Basin transect along the Weatherford Trail appeared to have relatively few, very small patches compared to the rest of the transect. Based on topography, we

${ }^{1}$ USDA Forest Service, Rocky Mountain Research Station, Flagstaff, AZ 86001.

${ }^{2}$ E-mail: alpineworkshop@gmail.com 


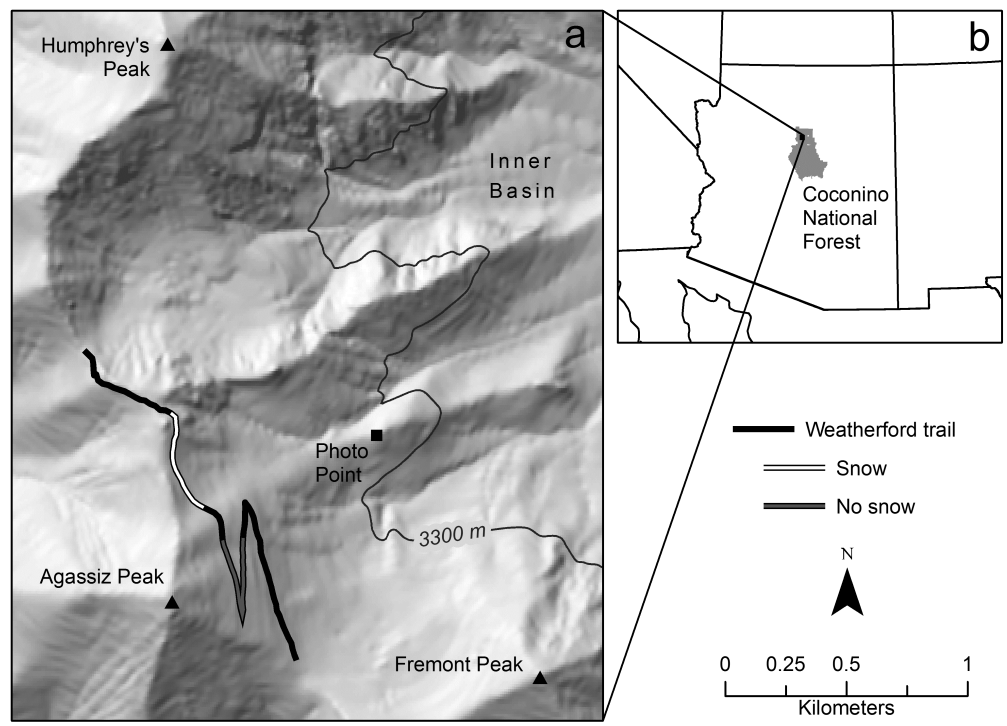

Fig. 1. Study area map for the relationship between snow duration and Packera franciscana abundance in northern Arizona, USA, showing (a) the 3 major San Francisco Mountain peaks on the edge of its collapsed caldera with the resulting Inner Basin to the east, and (b) its geographic position within Arizona.

suggest that this may be due to longer snow cover on that segment compared to the general landscape. The purpose of this note is to describe the relationship between winter snow duration, $P$. franciscana abundance, and possible environmental limitations. Quantifying this relationship could facilitate the understanding of future population trends if global warming leads to decreased snowfall.

To document 2013 snow duration and extent, photographs were taken during the spring from the same point (3355 m elevation) within the Inner Basin of the San Francisco Peaks caldera (Fig. 1). Photographs were taken at midday at 1-week intervals from 17 May to 14 June with a Nikkor 18-55-mm VR lens mounted to a Nikon D5000 camera, except for the initial photograph on 17 May which was taken with a (6-mm focal length) Samsung CL65 camera. However, camera height, focal length, and photograph frames varied slightly among the photographs (Fig. 2). Focal length of the Nikkor lens was $26 \mathrm{~mm}$ for 31 May and $18 \mathrm{~mm}$ for 24 May, 6 June, and 14 June. The photographs have not been altered. Snow-free and snowbed sample segments from the Weatherford Trail plant density data (Fowler et al. 2015) were delineated based on the 17 May snowbed photograph (Fig. 2). Packera franciscana ramets were counted at 25-m intervals along both edges of the Weatherford Trail in the snow-free and snowbed segments (Fig. 1), $500 \mathrm{~m}$ and $350 \mathrm{~m}$ long, respectively.

The snowbed northeast of Agassiz Peak covered most of the Weatherford Trail in the upper part of the concave topography above Snowslide Canyon on 17 May 2013 (Fig. 2). We noted evidence of past avalanches in the Engelmann spruce (Picea engelmannii Parry ex Engelmann) treeline ecotone directly below the snowbed and within the aptly named canyon. Snow cover along the Weatherford Trail and the overall alpine zone had mostly disappeared by mid-June (Fig. 2). The section of the Weatherford Trail under snow on 17 May 2013 (Fig. 2) had a 5-year arithmetic mean of 1.53 P. franciscana ramets $\cdot \mathrm{m}^{-2}(\mathrm{SE}$ 0.37 ), making this section much less dense than the snow-free section of the trail, which had a 5-year arithmetic mean of 7.17 ramets . $\mathrm{m}^{-2}$ (SE 1.09). A generalized linear model statistical analysis using a zero-inflated negative binomial distribution for ramet counts over 5 years of data collection at these points showed a significant difference in ramet counts between the snowbed and snow-free sections of the Weatherford Trail (count model: nb $\chi_{1,0.05}^{2}$ $=15.69, P<0.0001$; zero model: $\chi_{1,0.05}^{2}=$ 14.03, $P=0.0002$ SAS/STAT 12.1 Proc Genmod). This analysis models where plants 


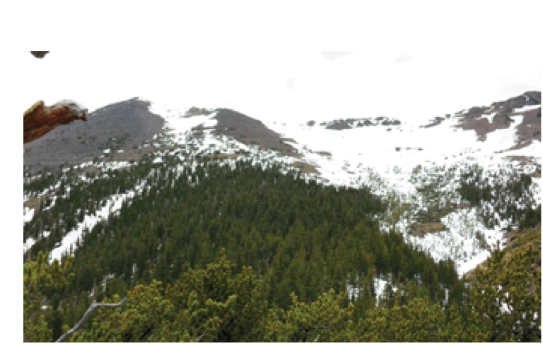

17 May 2013

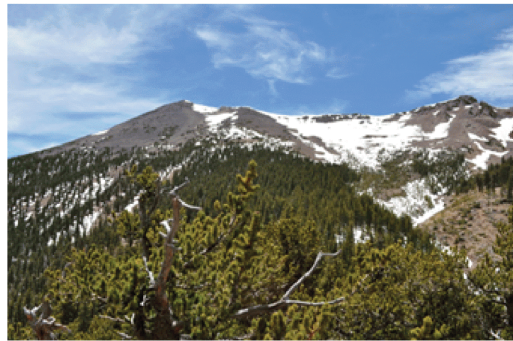

24 May 2013

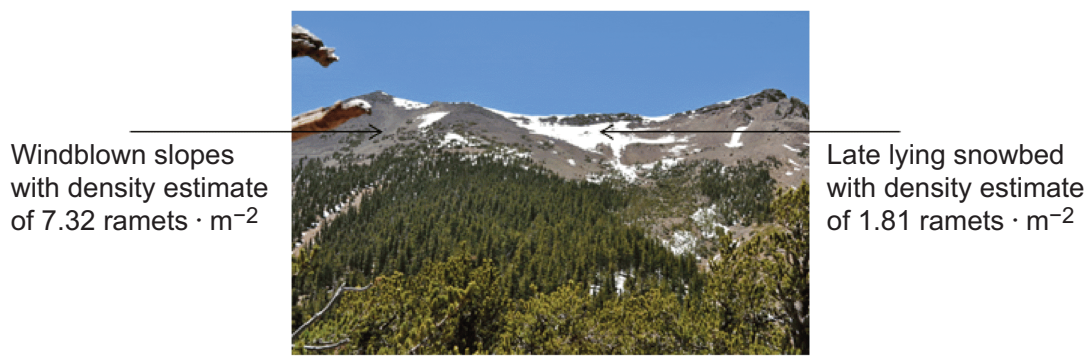

31 May 2013

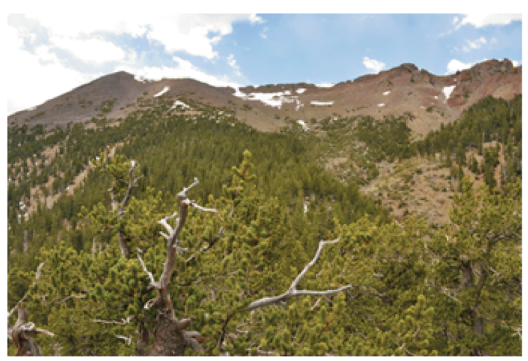

6 June 2013

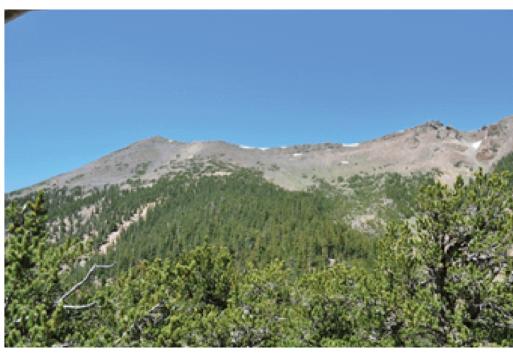

14 June 2013

Fig. 2. Photo series of snowbed melt within the Inner Basin of the San Francisco Peaks of northern Arizona. Photo point is looking east toward Agassiz Peak $(3766 \mathrm{~m})$, the leftmost peak. Packera franciscana is much less dense in midSeptember where the snowbed is most persistent in the spring.

TABLE 1. Comparison of annual means for Packera franciscana ramet density between snowbed and snow-free segments of the Weatherford Trail within the Inner Basin of the San Francisco Peaks in northern Arizona. Density is given as ramets $\cdot \mathrm{m}^{-2}$. Standard errors are in parentheses.

\begin{tabular}{ccc}
\hline Year & Snowbed density & Snow-free density \\
\hline 2009 & $1.82(1.07)$ & $4.76(1.72)$ \\
2010 & $2.05(0.67)$ & $8.30(2.36)$ \\
2011 & $1.29(0.49)$ & $8.29(2.35)$ \\
2012 & $1.34(1.16)$ & $7.12(2.90)$ \\
2013 & $0.67(0.36)$ & $7.41(2.88)$ \\
\hline
\end{tabular}

occurred as well as the inflated number of sample points where plants did not occur on both sections. The same analysis showed no significant difference between years (2009-2013, $\mathrm{nb} \chi_{4,0.05}^{2}=0.72, P=0.9489$; zero $\chi_{4,0.05}^{2}=$ $2.84, P=0.5845$; Table 1). Maximum likelihood parameter estimates indicate both lower ramet counts and more zero counts on the snowbed section. This area is the only extensive late-spring melting snowbed on the San Francisco Peaks, thus inferential power is limited to this site.

Deep snow cover stabilizes soil surface temperature to near freezing (Fowler unpublished data) and should also reduce the amount of light reaching the plants below. The difference in snow duration between the snow-free and snowbed segments along the Weatherford Trail (Fig. 2) may be the result of differences in topographic position leading to different 
early spring temperature regimes. However, we have observed green and photosynthetic $P$. franciscana from mid-October to early November in areas where it is abundant, well into the overnight freezing temperature season at $3500 \mathrm{~m}$ elevation and $35^{\circ} \mathrm{N}$ latitude. Although the snowbed segment is about $50 \mathrm{~m}$ higher in elevation than the snow-free segment, $P$. franciscana does grow in large patches at higher elevations with similar aspect. Light reduction via snow cover in late spring may explain the differences in abundance.

Alternatively, unstable talus slopes, especially during snowmelt with its potential for needle ice, may inhibit successful establishment of new patches of $P$. franciscana plants. Our study site is within Lawler's (1988) latitudealtitude zone of potential needle ice. Needle ice is the probable cause of surface frost heave (Haasis 1923, Fahey 1973) and may also contribute to talus creep (Perez 1985). Fahey (1973) and Haasis (1923) have shown that needle ice is mostly restricted to the soil surface layer and may lift the actual surface by as much as $10 \mathrm{~mm}$ to $50 \mathrm{~mm}$, leading to seedling death. Moisture and temperature conditions for needle ice formation (Perez 1985, Körner 2003, Lawler 1988) may be present during snowmelt periods (Beaty 1974) within the snowbed segment of the Weatherford Trail. Several studies have shown that the upper portion of talus slopes moves downslope faster than mid- and lower slope portions by "talus shift" (Gardner 1969, 1973, Perez 1985), which includes single surface layer movement, overturning, and superimposition along with general downslope movement (Gardner 1969). Unstable talus may in part be the result of spring diurnal freezethaw cycles and/or needle ice formation as well as gravitational processes working on surface particle size and slope angle (Perez 1985). Reports of mean distances for annual talus movement on previously measured upper talus cross-slope transects where the particle size is smaller include a range of 6$111 \mathrm{~cm} \cdot$ year $^{-1}$ in the Canadian Rocky Mountains (Gardner 1973) and an average of $9.5 \mathrm{~cm}$. year $^{-1}$ in the Andean páramo (alpine; Perez 1985). The Canadian Rockies are snow covered for 6-9 months of the year (Gardner 1979) while the Andean site does not have snow but does have high-frequency diurnal freeze-thaw cycles during the rainy season.
These studies also show high spatiotemporal variation in movement distances.

For upper talus directly below the rockfall zone, previous studies of alpine talus slope angle show a maximum of $36^{\circ}$ in the Canadian Rockies (Gardner 1979) and a $30^{\circ}-34^{\circ}$ range in the Andean páramo (Perez 1995). Using digital elevation models from the U.S. Forest Service Remote Sensing Applications Center, we measured a $35^{\circ}-36^{\circ}$ angle for the upper talus slope on the San Francisco Peaks where the Weatherford Trail crosses the snowbed segment and $P$. franciscana ramets were present at a low density. Perez (1995) examined an alpine talus slope toposequence for distribution of 4 caulescent rosette plant species in the Andean páramo and found that only Coespeletia timotensis Cuatr. occupied the upper, more unstable slopes of a talus profile. This plant was found in low densities clustered around large boulders embedded in the talus. Similarly, our site had relatively low-density measurements of $P$. franciscana along the snowbed segment where most plants grew in small patches near the outer, more stable, relatively flat edge of the Weatherford Trail maintained by the Coconino National Forest. Perez (1995) also gives a $24^{\circ}-27^{\circ}$ slope angle range for the middle, more stable portion of the Andean toposequence and indicates a sudden rise in rosette plant species density at the slope transition. We measured a $29^{\circ}-30^{\circ}$ slope angle on the windswept, snow-free segment of the Weatherford Trail where $P$. franciscana density is 4 times higher than in the snowbed segment.

Even with small wind-dispersed seed (Barkley 1988) and seed viability rates of over $60 \%$ (Fowler unpublished data), successful $P$. franciscana colonization of less-stable upper talus slopes is unlikely given downslope movement and an overturning substrate, especially during frost heave or needle ice formation periods which are known to uproot seedlings (Haasis 1923, Lawler 1988, Körner 2003). Our hypothesis is that active talus shift inhibits $P$. franciscana colonization and growth on upper talus slopes via high seedling mortality, especially in the snowbed with its potential for needle ice formation during spring snowmelt. Within its volcanic talus habitat, the relative paucity of $P$. franciscana ramets on the upper snowbed segment of the Weatherford Trail with slope angles of $35^{\circ}$ may simply result from greater talus surface 
instability; whereas higher abundance of $P$. franciscana on the snow-free segment may be attributed to the more stable windswept talus with slope angles of $29^{\circ}-30^{\circ}$ and to the shallow root systems of $P$. franciscana that may allow plants to "float" on the surface of mobile soils (Jonasson and Callaghan 1992, Fowler and Sieg 2010).

Financial support for this research was provided by the Coconino National Forest and the Rocky Mountain Research Station (RMRS), Forest and Woodland Ecosystems Science Program. Ben Bright prepared Fig. 1. We thank our field crew members for dedication to this work: Brian Casavant, Addie Hite, Scott Vojta, and Suzanne Owen. Voucher specimens were collected under U.S. Fish and Wildlife permit TE225821-0 and are deposited in the RMRS Flagstaff Herbarium (ASUF).

\section{Literature Cited}

Barbour, M.G., J.H. BuRK, AND W.D. PitTs. 1987. Terrestrial plant ecology. 2nd edition. Benjamin/Cummings, Menlo Park, CA.

BARKLEY, T.M. 1962. A revision of Senecio aureus Linn. and allied species. Transactions of the Kansas Academy of Science 65:318-364.

Barkley, T.M. 1968. Taxonomy of Senecio multilobatus and its allies. Brittonia 20:267-284.

BARKLEY, T.M. 1988. Variation among the Aureoid Senecios of North America: a geohistorical interpretation. Botanical Review 54:82-106.

BEaty, C.B. 1974. Needle ice and wind in the White Mountains of California. Geology 2:565-567.

FAHEY, B.D. 1973. An analysis of diurnal freeze-thaw and frost heave cycles in the Indian Peaks region of the Colorado Front Range. Arctic and Alpine Research 5:269-281.

Fowler, J.F., B.E. Nelson, and R.L. Hartman. 2014 Vascular plant flora of the alpine zone in the Southern Rocky Mountains, U.S.A. Journal of the Botanical Research Institute of Texas 8:611-636.

Fowler, J.F., AND C.H. SIEG. 2010. Density and elevational distribution of the San Francisco Peaks groundsel,
Packera franciscana (Asteraceae), a threatened singlemountain endemic. Madroño 57:213-219.

Fowler, J.F., C.H. Sieg, and S. Hedwall. 2015. Baselines to detect population stability of the threatened alpine plant Packera franciscana (Asteraceae). Western North American Naturalist 75:70-77.

GaRDNER, J.S. 1969. Observations of surficial talus movement. Zeitschrift für Geomorphologie 13:317-323.

Gardner, J.S. 1973. The nature of talus shift on alpine talus slopes: an example from the Canadian Rocky Mountains. Pages 95-106 in B.D. Faher and R.D. Thompson, editors, Research in Polar and Alpine Geomorphology. Geo Abstracts Ltd., Norwich.

Gardner, J.S. 1979. The movement of material on debris slopes in the Canadian Rocky Mountains. Zeitschrift für Geomorphologie 23:45-57.

Greene, E.L. 1889. New or noteworthy species. Pittonia 2:13-24.

Greenman, J.M. 1917. Monograph of the North and Central American species of the genus Senecio, pt. 2. Annals of the Missouri Botanical Garden 4:15-36.

HaAsIS, F.W. 1923. Frost heaving of western yellow pine seedlings. Ecology 4:378-390.

Jonasson, S., AND T.V. Callaghan. 1992. Root mechanical properties related to disturbed and stressed habitats in the Arctic. New Phytologist 122:179-186.

KöRNER, C. 2003. Alpine plant life, functional plant ecology of high mountain ecosystems. Springer, Berlin, Germany.

LAWLER, D.M. 1988. Environmental limits of needle ice: a global survey. Arctic and Alpine Research 20:137-159.

Perez, F.L. 1985. Surficial talus movement in an Andean paramo of Venezuela. Geografiska Annelar 67:221-237.

PerEZ, F.L. 1995. A high-Andean toposequence: the geoecology of caulescent paramo rosettes. Mountain Research and Development 15:133-152.

Trock, D.K. 2006. Packera. Pages 570-602 in Flora of North America Editorial Committee, editor, Flora of North America north of Mexico. Volume 20, Magnoliophyta: Asteridae, Pt. 7: Asteraceae, pt. 2. Oxford University Press, New York, NY.

[USFWS] United States Fish and Wildlife Service. 1983. Endangered and threatened wildlife and plants: final rule to determine Senecio franciscanus (San Francisco Peaks groundsel) to be a threatened species and determination of its critical habitat. Federal Register 48:52743-52747.

Received 2 February 2016 Accepted 26 April 2016 